\title{
ASPEK HUKUM PENYELESAIAN SENGKETA SECARA MEDIASI TERHADAP KONFLIK ANTARA NASABAH DENGAN PIHAK BANK
}

\author{
Dra. Deliani, SH,M.Hum \\ Universitas Amir Hamzah \\ deliani@gmail.com
}

\begin{abstract}
Abstrak
Penambahan cabang-cabang Bank dan pelayanan bank telah telah menjangkau sektor pedesaan dan masyarakat didorong untuk membuka rekening sekecil apapun. Dalam rangka menarik minat nasabah untuk menyimpan dana dalam bank, beberapa bank mengadkan undian, menawarkan hadiah-hadiah, mempromosikan iklan-iklan yang lihai, menawarkan bunga dan biaya-biaya yang lebih menarik. Kegiatan penghimpunan dana bagi bank pada masyarakat itu meliputi transaksi-transaksi dalam pemberian kredit , pemanfaatan sarana sarana dan fasilitas bank seperti penyediaan kartu kredit, ATM, surat-surat berharga dan lain-lain. Dari pemaparan diatas, maka jelaslah bahwa kedudukan bank adalah sebagai lembaga yang berhubungan erat dengan masyarakat dan mempunyai hubungan intermediasi dengan masyarakat itu sendiri. Dalam perspektif Undang-Undang Nomor 8 Tahun 1999 tentang perlindungan konsumen yang telah diatur dalam pasal 4 Undang-Undang Perlindungan Konsumen yang mengatur mengenai hak dan kewajiban konsumen, baik perjanjian simpanan maupun perjanjian kredit, kedudukan nasabah bank merupakan konsumen yang harus memperoleh perlindungan hukum. Perlindungan hukum bagi nasabah bank seharusnya sudah dilakukan pada tahap pra-perjanjian sampai dengan pelaksanaan perjanjian . Ketika hubungan hukun antar Bank dengan nasabah mulai tercipta, maka sejak itu terbuka kemungkinan sengketa antara pihak. Penyelesaian sengketa antar pihak tersebut dapat dilakukan melalui proses litigasi dan non litigasi.
\end{abstract}

Keyword : Hukum Penyelesaian Sengketa, Konflik Nasabah .

Jurnal Insitusi Politeknik Ganesha Medan 


\section{PENDAHULUAN}

Arti dan peran Perbankan terlihat dari pengertian Bank itu sendiri yakni badan usaha yang menghimpun dana dari masyarakat dalam bentuk simpanan dan menyalurkan ke masyarakat dalam bentuk pinjaman bantuan kredit dan atau bentuk-bentuk lainnya dalam rangka meningkatkan taraf hidup rakyat banyak . Lembaga perbankan meruakan inti dari sistem keuangan setiap Negara. Bank adalah lembaga keuangan yang menjadi tempat bagi orang perseorangan, badanbadan usaha swasta , Badan-badan usaha milik Negara, Bahkan lembaga-lembaga pemerintahan menyimpan dana-dana yang dimilikinya. Melalui kegiatan perkreditan dan berbagai jasa lainnya, bank berperan serta dalam mekanisme pembayaran bagi semua sektor perekonomian . Prasarana perbankan Indonesia setelah reformasi mengalami perkembangan yang sangat cepat. Praktek perbankan selama ini dalam menyelesaikan sengketa belum banyak menggunakan proses non-litigasi . Hal ini dapat dilihat dari perjanjian-perjanjian yang dibuat antara bank dan nasabah yang tidak mencantumkan klausula seperti arbitrase, mediasi dan sebagainya seperti yang dikemukakan dalam Undang-Undang Nomor 30 Tahun 1999 tentang Arbitrase dan Alternatif Penyelesaian Sengketa. Penyelesaian Sengketa, baik melalui pengadilan ataupun arbitrase bersifat formal, memaksa melihat masalah kebelakang dengan memperhatikan ciri pertentangan dan apa yang mendasarkan hak-hak. Penyelesaian sengketa melalui perdamaina secara mediasi tampaknya mempunyai prospek dan peluang untuk dikembangkan serta diberdayakan di pengadilan, namun, tidak mengurangi pentingnya peranan peradilan formal. Keduanya tetap dibutuhkan dalam dunia praktik hukum, Untuk itu, mediasi dan proses peradilan formal dikolaborasikan agar terwujud azas peradilan sederhana, cepat dan biaya ringan.

\section{KAJIAN PUSTAKA}

\section{A. Hubungan Hukum Bank Dengan Nasabah Berdasarkan Hukum Kontrak.}

Hubungan antara Nasabah dan bank didasarkan pada dua unsur yang paling terkait, yakni hukum dan kepercayaan. Suatu Bank hanya bisa melakukan kegiatan dan mengembangkan Banknya apabila masyarakat percaya untuk menyimpan uangnya pada produk-produk perbankan yang ada pada bank tersebut. Hukum kontrak yang menjadi dasar terhadap hubungan Bank dan Nasabah debitur bersumber dari ketentuan-ketentuan KUH Perdata tentang kontrak (buku III) sebab, menurut pasal 1338 ayat (1) KUH Perdata, bahwa semua perjanjian yang dibuat secara sah berkekuatan sama dengan Undang-Undang bagi kedua belah pihak. Selain itu, perjanjian kredit Bank diatur juga oleh ketentuan khusus mengenai "pinjam pakai habis" (Verbruiklening) Vide pasal 1754 sampai pasal 1769 KUH Perdata. 
Hubungan hukum antar nasabah dan Bank timbul dari perjanjian yang ditandatangani oleh kedua belah pihak sebagai tanda kesepakatan . Segala hak dan kewajiban masing-masing pihak, yaitu nasabah dan Bank, didasarkan atas perjanjian yang mereka buat. Berdasarkan dua fungsi utama dari bank yakni fungsi pengerahan dan penyaluran dana, maka terdapat dua hubungan yang lazim antara bank dengan Nasabah yaitu :

a. Hubungan hukum antara Bank dengan Nasabah penyimpan dana, bentuk hubungan hukum itu dituangkan dalam bentuk peraturan bank yang bersangkutan dan syarat-syarat umum yang harus dipenuhi oleh setiap nasabah penyimpan dana.

b. Hubungan Hukum antara bank dan Nasabah Debitur, Bentuk hubungan hukum yang demikian ini memberikan pemahaman bahwa bank merupakan lembaga penyedia dana bagi para debiturnya . Dalam Undang-Undang Nomor 10 Tahun 1998 hubungan tersebut dimaknai sebagai hubungan nasabah yang memperoleh fasilitas kredit atau pembiayaan berdasarkan prinsip syariah atau yang disamakan dengan itu berdasarkan perjanjian antara nasabah dengan Bank yang bersangkutan.

Hubungan hukum anatara Nasabah dengan Bank timbul dari perjanjian yang ditandatangani oleh kedua belah piham sebagai tanda kesepakatan . Segala hak dan kewajiban masing-masing pihak, yaitu Nasabah dengan Bank, didasarkan atas perjanjian yang mereka buat.

Suatu perikatan atau perjanjian adalah suatu hubungan hukum antara dua orang atau dua pihak, berdasarkan mana pihak yang satu berhak menuntut sesuatu hal dari poihak yang lain, dan pihak yang lain berkewajiban untuk memenuhi tuntutan itu.

\section{Jenis dan Sumber Data}

\section{METODE PENELITIAN}

Dalam penelitian ini penulis akan menggunakan data yang berhubungan dengan permasalahan dan tujuan dari penelitian . Adapun jenis dan sumber data yang akan dipergunakan dalam penelitian ini adalah :

a. Data Primer

Data ini didapat dari hasil penelitian yang dilakukan dilapangan langsung dengan melakukan tatap muka, wawancara dari pihak Bank Perkreditan Rakyat PT BPR Perbaungan.

b. Data Sekunder.

Data ini adalah data yang didapat melalui literatur yang tersedia (Kepustakaan) yang terdiri dari buku-buku materi yang berisikan halhal yang berkaitan dengan mediasi perbankan dan Alternatif penyelesaian perselisihan perkara dan beberapa peraturang perundangundangan yang berkaitan dengan permasalahan yang akan diteliti. 


\section{Tekknik Pengumpulan Data}

Sebagai tindak lanjut dalam rangka memperoleh data sebagaimana yang diharapkan maka penulis akan melakukan teknik pengumpulan data sebagai berikut :

a. Wawancara.

Penelitian untuk medapatkan data primer, maka penulis akan melakukan tatap muka atau wawancara kepada para pihak yang terkait yakni pihak PT BPR dengan menggunakan wawancara langsung sesuai dengan pedoman wawancara yang telah ditetapkan dan dibuat yang akan ditujukan kepada para narasumber.

b. Dokumentasi.

Untuk melengkapi data pendukung penelitian, maka penulis akan melengkapinya dengan mengumpulkan segala dokumen-dokumen pendukung yang mengandung data-data yang nantinya akan dilakukan analisis terhadap data-data yang ada dan yang mempunyai hubungan dengan permasalahan yang ada dalam penelitian ini dan untuk mendapatkan data skunder .

\section{Analisis Data.}

Data yang telah diperoleh ( Data Primer dan Sekunder) akan diolah dan segera dilakukan analisis secara kwalitatif dan kwantitatif untuk melihat permasalahan mengenai penyelesaian sengketa antara Bank dengan Nasabah melalui mediasi ditinjau dari ketentuan perbankan dan selanjutnya akan disajikan secara deskriptif.

\section{DISCUSSION}

\section{A. Penyebab Munculnya Sengketa.}

Dalam upaya mengurangi berbagai keluhan dari nasabah tersebut, maka Bank Indonesia sebagai Bank Sentral Indonesia mengeluarkan peraturan yang menjadi dasar hukum bagi nasabah untuk menyatakan ketidakpuasannya dan mengajukan aduan kepada pihak perbankan . Berdasarkan peraturan Bank Indonesia nomor 7/7/PBI/2005 Tentang penyelesaian pengaduan nasabah, melalui kebijakan ini, maka diberi kesempatan bagi nasabah untuk menyampaikan segala ketidakpuasannya terhadap berbagai jenis transaksi perbankan yang dilakukan. Kemudian karena dirasa kurang dapat memuaskan nasabah, bank Indonesia mengambil inisiatif untuk mengeluarkan Peraturan bank Indonesia Nomor 8/5/PBI/2006 sebagaimana yang telah diubah dengan PBI No.10/1/PBI/2008, Tentang Mediasi perbankan.

Terkait dengan peranan dan fungsi lembaga mediasi perbankan dalam berperan menyelesaikan persoalan yang terjadi akibat munculnya sengketa antara bank denban nasabahnya dalam hal pelayanan perbankan seperti :

a. Kegagalan Transfer

b. Terdebitnya rekening nasabah maupun 
c. Dalam hal kredit bermasalah antara lain perlakuan kasar dan salah dari bank

d. Dalam hal penaguhan maupun

e. Keslaahan dalam hal eksekusi hak tanggungan / Jaminan lainnya

Dalam hal mediasi yang dilakukan oleh pihak bank dan nasabah itu, ada tatacara yang dilakukan dalam menempuh penyelesaian sengketa antara bank dengan nasabah melalui mediasi tersebut yang sebelumnya telah diatur di dalam Peraturan Bank Indonesia Nomor : 8/5/PBI/2006, yang membatasi bahwa bank tidak dapat melakukan mediasi sejauh dari apa yang telah diatur dalam Peraturan Bank Indonesia tersebut, dengan kata lain, tata cara yang dilakukan bank dalam melaksanakan mediasi tidak boleh melebihi dari apa yang telah diatur dalam peraturan yang berlaku, dalam hal ini Peraturan Bank Indonesia, jadi tata cara penyelesaian sengketa antara bank dengann nasabah yang kami lakukan itu sama dengan tata pelaksanaaan mediasi sebagaimana yang telah diatur dalam PBI Nomor : 8/5/PBI/2006 Tentang Mediasi Perbankan.

\section{KESIMPULAN}

\section{A. Kesimpulan}

Dari hasil analisis dan pembahasan yang telah diuraikan sebelumnya, maka penulis menarik beberapa kesimpulan atas hasil analisis tersebut yaitu:

1. Dalam menyelesaikan sengketa antara bank dan nasabah, dapat ditempuh melalui jalur non-litigasi dalam menyelesaikan sengketa karena efektif dan efisien. Dalam hal ini proses mediasi dipandang sebagai proses yang lebih sederhana dari segi prosedur dan relatif lebih murah. Proses mediasi ini akan memungkinkan pihak-pihak untuk menentukan apa yang memuaskan dengan mengarahkan masalah-masalah sempit dalam konflik untuk fokus kepada situasi dan kondisi permasalahan sengketa. Mediator bersifat netral dan dapat membantu pihak-pihak dalam mengungkapkan agenda tersembunyi dan ungkapan emosional yang tidak terungkap melalui ketentuan pembuktian dan prosedur.

2. Dalam penerapan mediasi sebagai alternatif penyelesaian sengketa bank dan nasabah, proses mediasi dipandang sebagai proses yang lebih sederhana dari segi prosedur dan relatif lebih murah. Dalam sengketa antara bank dan nasabah, nasabah sering kali menjadi tidak berdaya pada saat harus berhadapan dengan Bank di Pengadilan dan hanya bisa pasrah apabila bersengketa dengan Bank. Agar nasabah dapat terlindung hakhaknya, dibentuklah mediasi perbankan yang berfungsi sebagai lembaga penyelesaian sengketa. Penyelesaian sengketa perbankan melalui mediasi perbankan sangat menguntungkan bagi nasabah kecil, sebab prosesnya sederhana, biaya murah, dan cepat.

\section{B. Saran}

Berdasarkan kesimpulan tersebut di atas, maka penulis mengajukan saran sebagai berikut : 
1. Dalam penerapan penyelesaian sengketa antara bank dan nasabah perlunya sosialisasi tentang mediasi perbankan yang harus lebih diperluas karena sangat menguntungkan nasabah kecil.

2. Disarankan perlu ditingkatkan mengenai standar mekanisme pengaduan nasabah. Mekanisme yang bersifat standar untuk bank akan memberikan manfaat yang sama kepada semua nasabah sehingga akan dapat menciptakan rasa kepercayaan yang tinggi dari nasabah kepada perbankan nasional. Hal ini akan sangat menguntungkan bagi pihak bank.

3. Untuk menjamin tumbuhnya kesadaran dan partisipasi yang luas dari masyarakat maka perlu sosialisasi tentang peran dan fungsi mediasi perbankan selama ini. Bahwa sangat disadari, di kalangan masyarakat masih banyak yang belum mengetahui tentang peran dan fungsi mediasi perbankan.

4. Disarankan untuk memilih mediator dalam penyelesaian sengketa, hendaknya saling menguntungkan antar kedua belah pihak dalam artian adil untuk kedua pihak. Yaitu mediator professional yang dapat ditunjuk oleh para pihak. Karena mediator professional diambil dan tidak ada hubungannya dengan salah satu pihak, jadi netral untuk keduanya.

\section{REFERENCES}

Abdullah Marlang, Pengantar Hukum Indonesia, Ed. 1, Jakarta:Citra Grafika, 2009.

Achmad Ali, Menguak Teori Hukum (Legal Theory) dan Teori Peradilan (Judicialprudence) Termasuk Interprestasi UndangUndang (Legispridence), Ed. 1, Cet. 1, Jakarta: Kencana, 2009.

2011

Menguak Tabir Hukum, Ed-2, Cet-3, Bogor: Ghalia Indonesia,

Gatot Supramono, Perbankan dan Masalah Kredit: Suatu Tinjauan Yuridis, Eds.Revisi, Cet-2, Jakarta: Djambatan, 1996.

Gunawan Widjaja, Alternatif Penyelesaian Sengketa (Seri Hukum Bisnis), Ed. 1, Jakarta: PT Raja Grafindo Persada, 2005.

Hermansyah, Hukum Perbankan Nasional Indonesia, Jakarta: Kencana, 2011

Huala Adolf, Hukum Penyelesaian Sengketa Internasional, Jakarta: Sinar Grafika, 2004.

Ishaq, Dasar-Dasar Ilmu Hukum, Ed-1. Cet. 2.-- Jakarta: Sinar Grafika, 2009.

Jimmy Joses Sembiring, Cara Menyelesaikan Sengketa di Luar Pengadilan, Cet1, Jakarta: Visimedia, 2011. 
Lukman Santoso, Hak Dan Kewajiban Hukum Nasabah Bank, Cet-1, Yogyakarta: Pustaka Yustisia, 2011.

Muhammad Djumhana, Hukum Perbankan Di Indonesia, Bandung: PT. Citra Aditya Bakti, 1996

Munir Fuady, Hukum Perbankan Modern Berdasarkan Undang-Undang Tahun 1998, Cet-1, Bandung : PT. Citra Aditya Bakti, 1999

Bakti, 1999.

Hukum Perbankan Modern, Cet-1, Bandung : PT. Citra Aditya

Nurnaningsi Amriani, MEDIASI Alternatif Penyelesaian Sengketa Perdata di Pengadilan, Jakarta: Rajawali Pers, 2011.

Peter Mahmud Marzuki , Pengantar Ilmu Hukum, Ed-1, Jakarta: Kencana, 2009. Rachmadi Usman, Aspek-Aspek Hukum Perbankan Indonesia, Jakarta: PT. Gramedia Pustaka Utama, 2001 